\section{THE STRUCTURE OF ANTRIMYCIN}

Sir :

In the previous paper ${ }^{1)}$, we reported the isolation of a new peptide antibiotic, antrimycin. In this communication, the structure determination of antrimycin is reported.

\section{${ }^{13} \mathrm{C}$ and ${ }^{1} \mathrm{H}$ NMR Spectra}

As described in the previous paper, the molecular formula was established as $\mathrm{C}_{28} \mathrm{H}_{47} \mathrm{~N}_{8} \mathrm{O}_{11}$ by elemental analysis and mass spectrometry. The ${ }^{13} \mathrm{C}$ NMR spectrum in $\mathrm{D}_{2} \mathrm{O}$ (Fig. 1) also indicated the presence of 28 carbons. The off-resonance spectrum showed that in the $\mathrm{sp}^{3}$-carbon region $(\delta$ $13.0 \sim 64.8)$ there are five methyls, six methylenes, six methines and one non-proton-bearing carbon $\left(\delta\right.$ 64.6), and in the $\mathrm{sp}^{2}$-carbon region $(\delta 122.5 \sim$ $176.8)$ there are seven carbons $(\delta 167.7 \sim 176.8)$ tentatively assigned to carbonyl, one methine $(\delta$ 149.2) and two non-proton-bearing carbons $(\delta$ $122.5,149.3)$. The multiplicity of the signals in the off-resonance spectrum is recorded in Fig. 1. The well-resolved $250 \mathrm{MHz}{ }^{1} \mathrm{H}$ NMR spectrum in $\mathrm{D}_{2} \mathrm{O}$ (Fig. 2) indicated the presence of 34 non-exchangeable protons, which was in accord with the proton number counted from the offresonance ${ }^{13} \mathrm{C}$ NMR spectrum. The ${ }^{1} \mathrm{H}^{-1} \mathrm{H}$

Fig. $1 .{ }^{13} \mathrm{C}$ NMR spectrum of antrimycin in $\mathrm{D}_{2} \mathrm{O}$ at $25.2 \mathrm{MHz}$.

(pHm 7.0, internal dioxane as $\delta$ 67.4)

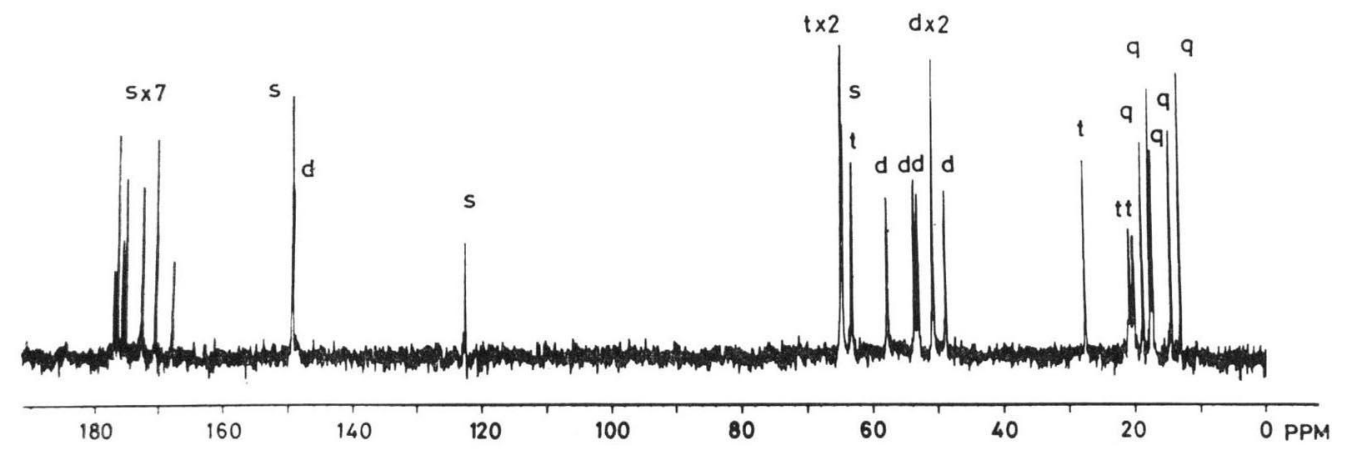

Fig. 2. ${ }^{1} \mathrm{H}$ NMR spectrum of antrimycin in $\mathrm{D}_{2} \mathrm{O}$ at $250 \mathrm{MHz}$.

(pHm 7.9, internal sodium 3-(trimethylsilyl)propionate- $d_{4}$ as $\delta 0$ )

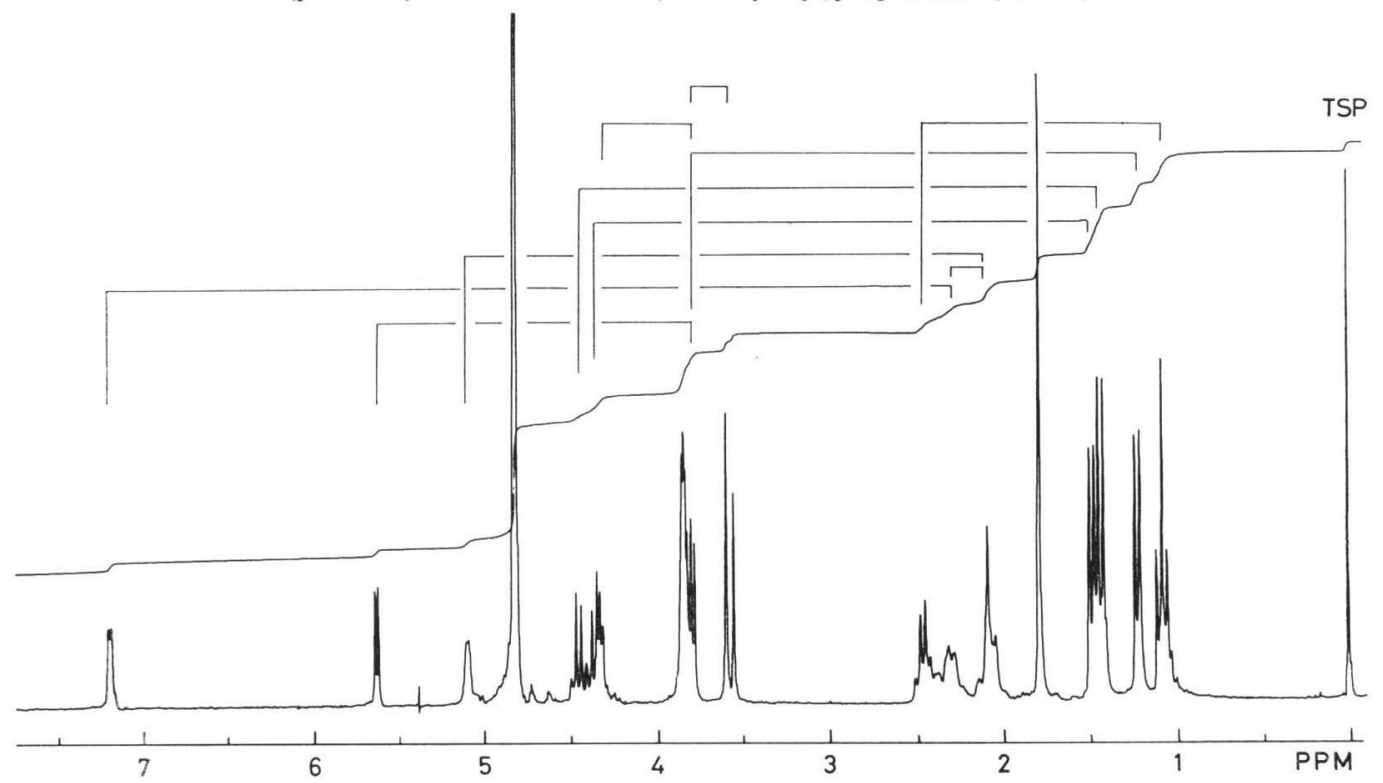


coupling relations are also shown in Fig. 2. All of the proton signals can be correlated to the proton-bearing carbon signals by the aid of selective ${ }^{13} \mathrm{C}-{ }^{1} \mathrm{H}$ decoupling (Data are not shown).

\section{Amino Acids Obtained by Total Acid Hydrolysis}

Total acid hydrolysis $\left(6 \mathrm{~N} \mathrm{HCl}, 110^{\circ} \mathrm{C}\right.$, 16 hours) of antrimycin gave four ninhydrin positive products. They were isolated by Dowex 50X8 column chromatography developed with pyridine-formate $(\mathrm{pH}$ 3.0) followed by pyridine acetate ( $\mathrm{pH} 4.6$ and 4.9 ) buffers. The two amino acids eluted secondly and thirdly were identified as L-serine, $[\alpha]_{\mathrm{D}}^{20}+13.2^{\circ}(c 0.5,6 \mathrm{~N} \mathrm{HCl})$, and Lalanine, $[\alpha]_{\mathrm{D}}^{21}+14.0^{\circ}(c 0.5,6 \mathrm{~N} \mathrm{HCl})$, respectively, but the other two were found to be uncommon.

The first eluted unusual amino acid was determined to be 2,2-bis(hydroxymethyl)glycine (BHMG). ${ }^{2)}$ Calcd. for $\mathrm{C}_{4} \mathrm{H}_{8} \mathrm{NO}_{4}$ (MW 135.12): C, 35.55; H, 6.71; N, 10.37. Found: C, 36.04, $\mathrm{H}, 6.64 ; \mathrm{N}, 10.20$. FDMS, $m / z 136(\mathrm{M}+\mathrm{H})^{+}$. ${ }^{1} \mathrm{H}$ NMR in $\mathrm{D}_{2} \mathrm{O} ; 3.95(2 \mathrm{H}, \mathrm{d}, 12.3 \mathrm{~Hz})$ and 4.10 $(2 \mathrm{H}, \mathrm{d}, 12.3 \mathrm{~Hz})$, external TMS reference at 100 MHz. ${ }^{13} \mathrm{C}$ NMR in $\mathrm{D}_{2} \mathrm{O} ; 173.7$ (s), 68.1 (s), $62.3 \times 2(\mathrm{t})$.

The last eluted basic amino acid was found to be a diastereoisomeric mixture (ca. 2:1) of 2,3diaminobutanoic acid (DABA) ${ }^{3,4)}$ by ${ }^{1} \mathrm{H}$ and ${ }^{13} \mathrm{C}$ NMR, and FD mass spectrometries $[\mathrm{m} / \mathrm{z} 119$ $\left.(\mathrm{M}+\mathrm{H})^{+}\right]$. The major component was isolated by crystallization from aqueous ethanol. It was identified as erythro-L- $\alpha, \beta$-diaminobutanoic acid, that is $(2 S, 3 S)$-DABA, by ${ }^{1} \mathrm{H}$ NMR $\left({ }^{1} \mathrm{H}_{\alpha^{-}}{ }^{1} \mathrm{H}_{\beta}\right.$ coupling constant $6.5 \mathrm{~Hz})^{3)}$ and ORD spectrometry (peak at $\left.226 \mathrm{~nm} 2400^{\circ}\right)^{3,4}$. It is already known that DABA is partially epimerized during acid hydrolysis. ${ }^{4)}$ Therefore, the $(2 S, 3 S)$-isomer should exist originally in antrimycin.

The molar ratio of the four amino acids in antrimycin was shown to be: BHMG - Ser - Ala DABA, $1: 1: 2: 1$, by ${ }^{1} \mathrm{H}$ NMR spectrometry of antrimycin. The molar ratio of Ala to Ser was also confirmed by amino acid analysis with a Hitachi 835 amino acid analyzer.

\section{Terminal Analysis}

Potentiometric titration of antrimycin indicated the presence of three dissociable functions ( $p \mathrm{Ka}$ 3.4, 6.4 and 8.5). Hydrazinolysis of antrimycin liberated serine. Therefore, the $p K a 3.4$ can be assigned to the carboxyl group of the serine.
Treatment of antrimycin with dinitrofluorobenzene followed by acid hydrolysis gave monoDNP-DABA and a trace of DNP-BHMG. In the ${ }^{1} \mathrm{H}$ NMR of antrimycin measured in DMSO$d_{8}$, the $\alpha$-methine proton of DABA appeared as doublets of doublet at $\delta 5.56\left[J, 9.0\left(\mathrm{C}_{\alpha} \mathrm{H}-\mathrm{NH}\right)\right.$ and $5.5\left(\mathrm{C}_{\alpha} \mathrm{H}-\mathrm{C}_{\beta} \mathrm{H}\right) \mathrm{Hz}$. It means that the $\alpha$ amino function of DABA is concerned in the peptide bond formation and the mono-DNPDABA described above is $\beta$-DNP-DABA. The poor yield of DNP-BHMG was suggested to be due to steric hindrance by vicinal bis(hydroxymethyl) groups. In fact, BHMG itself was hardly dinitrophenylated. Thus, it was concluded that the $\beta$-amino group of DABA and the amino group of BHMG are free in the antrimycin molecule. By the $\mathrm{pH}$-dependent ${ }^{13} \mathrm{C}$ chemical shift, $p K a 6.4$ is assigned to the amino group of $\mathrm{BHMG}$ and $p K a 8.5$ to the $\beta$-amino group of DABA (data are not shown).

Mild Alkaline Hydrolysis Products

From the total acid hydrolysate of antrimycin, information on the structure of the remaining $\mathrm{C}_{11} \mathrm{~N}_{3}$-containing moiety could not be obtained. Therefore, mild alkaline hydrolysis $(1 \mathrm{~N} \mathrm{NaOH}$, $37^{\circ} \mathrm{C}, 5$ days) was carried out to minimize decomposition and racemization. The alkaline hydrolysate was separated into two fractions: the effluent from Diaion HP-20 column and the eluate from the column with $50 \%$ aqueous acetone. The effluent contained a substance (THPC) which gave a yellow color by ninhydrin reaction. THPC was isolated as a sticky colorless material by Avicel column chromatography developed with $95 \%$ ethanol. The ${ }^{13} \mathrm{C}$ NMR spectrum in $\mathrm{D}_{2} \mathrm{O}$ showed the presence of 5 carbon atoms $(\delta 22.1$, 22.2, 56.3, 147.3 and 179.8). The result of the ${ }^{1} \mathrm{H}$ NMR study $[\delta 7.45(1 \mathrm{H}, \mathrm{m}), 2.76(2 \mathrm{H}, \mathrm{m})$, $2.55(2 \mathrm{H}, \mathrm{m}), 4.10(1 \mathrm{H}, \mathrm{m})]$ together with the ${ }^{13} \mathrm{C}$ NMR study suggested a ring structure having the following partial structure:

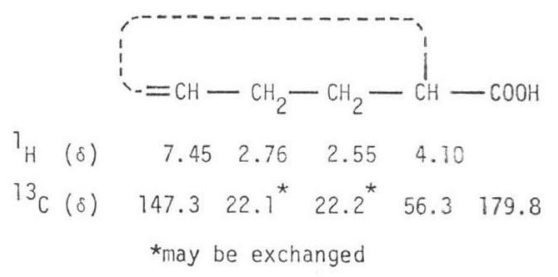




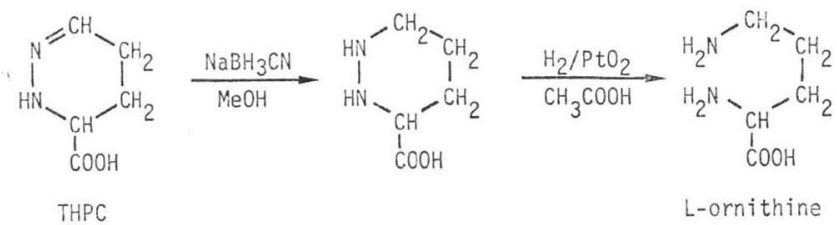

The presence of 2 nitrogen atoms in THPC was suggested by the $\mathrm{N} / \mathrm{C}$ atom ratio in the elemental analysis. The FD mass spectrum gave $\mathrm{M}^{+}$ion at $m / z 128$. Thus, the molecular formula was shown to be $\mathrm{C}_{5} \mathrm{H}_{8} \mathrm{~N}_{2} \mathrm{O}_{2}$ (MW 128). From this molecular formula and the partial structure described above, the structure of THPC was supposed to be 2,3,4,5-tetrahydropyridazine-3carboxylic acid.

To confirm this proposed structure, the transformation of THPC into ornithine was carried out. First, THPC was reduced with $\mathrm{NaBH}_{3} \mathrm{CN}$ in methanol at room temperature overnight to give a sticky dihydro-THPC $(m / z 130)$. The ${ }^{1} \mathrm{H}$ NMR spectrum showed the presence of $-\mathrm{CH}_{2}-$ $\mathrm{CH}_{2}-\mathrm{CH}_{2}-\stackrel{\prime}{\mathrm{C}} \mathrm{H}$ - sequence $[\delta 3.68(2 \mathrm{H}, \mathrm{m}), 2.60$ $(2 \mathrm{H}, \mathrm{m}), 2.36(2 \mathrm{H}, \mathrm{m})$ and $4.15(1 \mathrm{H}, \mathrm{m})]$. The dihydro-THPC was hydrogenated under 4 atomospher pressure of hydrogen with platinum catalyst for 2 days at room temperature in acetic acid to yield ornithine. It was identified by TLC, high voltage paper electrophoresis and amino acid analysis. The ORD spectrum in $1 \mathrm{~N} \mathrm{HCl}$ showed a peak at $226 \mathrm{~nm}\left(1400^{\circ}\right)$; authentic L-ornithine $\left(226 \mathrm{~nm}, 2870^{\circ}\right)$. From the result, the stereochemistry of the derived ornithine was shown to be partially racemized L-isomer. Thus, the presence of an $(S)$-2,3,4,5-tetrahydropyridazine-3carboxylic acid moiety in antrimycin was disclosed.

The eluate fraction from Diaion HP-20 of the alkaline hydrolysate contained two ninhydrin positive products as the major components: one gave a violet color (Peptide-B1) and the other a yellow color (Peptide-B2) with the ninhydrin reaction. They were isolated by preparative Avicel TLC. Peptide-B1 was also found as a minor component in the effluent from the Diaion HP-20 column.

Acid hydrolysis of Peptide-B1 yielded one mole each of alanine and serine. The $\mathrm{N}$-terminus was determined to be alanine by DNP-method. The ${ }^{13} \mathrm{C}$ NMR spectrum in $\mathrm{D}_{2} \mathrm{O}$ showed the presence of 6 carbon signals [o 13.0 (q), 18.1 (q), $27.5(\mathrm{t}), 122.7(\mathrm{~s}), 147.2(\mathrm{~s})$ and one of three carbonyl signals], which remained to be solved in antrimycin molecule, in addition to 6 signals ascribed to alanine and serine. The ${ }^{1} \mathrm{H}$ NMR spectrum also showed the presence of the unclarified ethyl $[\delta 1.60(3 \mathrm{H}, \mathrm{t}, 7.5 \mathrm{~Hz}), 2.93(2 \mathrm{H}, \mathrm{q}$, $7.5 \mathrm{~Hz})]$ and methyl $[\delta 2.32(3 \mathrm{H}, \mathrm{s})]$ signals in addition to the signals of alanine and serine. Thus, Peptide-B1 was supposed to be a tripeptide, alanyl-dehydroisoleucyl-serine (MW 287). In fact, the FD mass spectrum of Peptide-B1 gave a peak at $m / z 288(\mathrm{M}+\mathrm{H})^{+}$. To confirm the structure, Peptide-B1 was hydrogenolyzed under 4 atomospher pressure of hydrogen with platinum catalyst for 2 days at room temperature in $1 \mathrm{~N}$ acetic acid. The product was hydrolyzed in $6 \mathrm{~N}$ $\mathrm{HCl}$ at $110^{\circ} \mathrm{C}$ overnight. Amino acid analysis indicated the presence of almost one mole each of alanine, serine, and isoleucine, and a trace amount of allo-isoleucine. Thus, the structure of Peptide-B1 was determined to be L-alanyl- $(E)$ (2,3-didehydroisoleucyl)-L-serine.

All of the signals of ${ }^{1} \mathrm{H}$ and ${ }^{13} \mathrm{C}$ NMR spectra of antrimycin can be explained by the seven amino acids hitherto characterized: 2 moles of Ala, one mole each of Ser, BHMG, DABA, THPC and $\triangle$-Ile (dehydroisoleucine). The results described above indicate that antrimycin is a linear heptapeptide, of which the $\mathrm{N}$-terminus is BHMG and
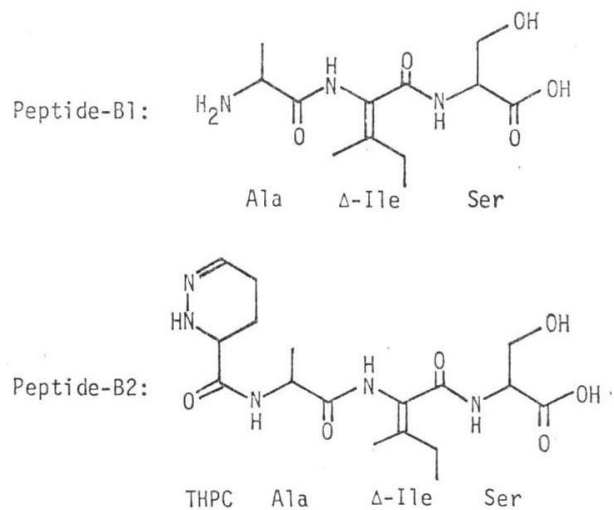
Fig. 3. Structure of antrimycin.<smiles>CC/C(C)=C(/NC(=O)C(C)NC(=O)[C@H]1CCC=NN1C(=O)[C@H](NC(=O)[C@H](C)NC(=O)C(N)(CO)CO)C(C)N)C(=O)N[C@@H](CO)C(=O)O</smiles>

the $\mathrm{C}$-terminus is serine, with the free $\beta$-amino function of DABA.

The ${ }^{1} \mathrm{H}$ and ${ }^{13} \mathrm{C}$ NMR spectra of Peptide-B2 suggested that Peptide-B2 is the C-terminal tetrapeptide of antrimycin: THPC-Ala- $\Delta$-Ile-Ser.

Mild Acidic Hydrolysis Products

In order to determine the total amino acid sequence in antrimycin, partial acidic hydrolysis of antrimycin $\left(6 \mathrm{~N} \mathrm{HCl}, 37^{\circ} \mathrm{C}, 6\right.$ days) was carried out. The hydrolysates were separated by Dowex 50-X8 column chromatography developed with pyridine-formate ( $\mathrm{pH} 3.0$ ) followed by pyridineacetate (pH 4.6 and 4.9) buffers. Four segment peptides were isolated and named Peptides-A1, $-\mathrm{A} 2,-\mathrm{A} 3$ and $-\mathrm{A} 4$ in order of the elution.

Peptide-A1 was found to be identical with Peptide-B1. Peptide-A2 was found to be the Nterminal dipeptide, BHMG-Ala, by total acid hydrolysis and NMR studies. Peptide-A3 was found to be a pentapeptide composed of one mole each of DABA, THPC, Ala, $\triangle$-Ile and Ser by

$$
\text { Peptide-Al }=\text { Peptide-B1 }
$$

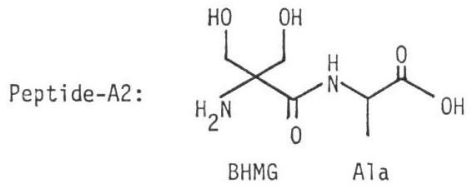

Peptide-A3: (DABA-THPC-Ala- $\triangle$-Ile-Ser)

Peptide-A4:

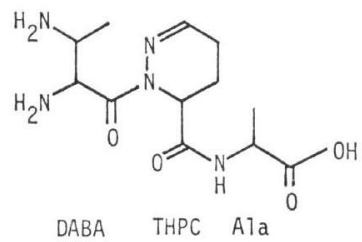

NMR studies. Peptide-A4 was found to be a tripeptide, DABA-THPC-Ala, by total acid hydrolysis, N-terminal analysis (DNP-method), FDMS $m / z 300(\mathrm{M}+\mathrm{H})^{+}$, and NMR studies.

From the experimental results described above, the structure of antrimycin, including the absolute configuration, has been determined to be that shown in Fig. 3.

\section{Acknowledgement}

The authors are grateful to Messrs. T. SHIMAzu and S. Seto, Nippon Kayaku Co. Ltd., for amino acid analysis.

\section{KazUSHI MoRimoto Nobuyoshi Shimada Hiroshi Naganawa TOMOHISA TAKITA Hamao UmezaWA}

Institute of Microbial Chemistry, 14-23 Kamiosaki 3-chome, Shinagawa-ku, Tokyo 141, Japan

(Received September 9, 1981)

\section{References}

1) Shimada, N.; K. Morimoto, H. Naganawa, T. Takita, M. Hamada, K. Maeda, T. Takeuchi \& H. Umezawa: Antrimycin, a new peptide antibiotic. J. Antibiotics 34: 1613 1614, 1981

2) Greenstein, J. P. \& M. Winitz: Chemistry of the Amino Acids. p. 2221, John Wiley \& Sons Inc., New York·London, 1961

3) Hausmann, W. K.; D. B. Borders \& J. E. LANCASTER: $\alpha, \beta$-Diaminobutyric acid obtained from aspartocin. J. Antibiotics 22: 207 210, 1969

4) Bodanszky, A. A. \& M. Bodanszky: Two diastereoisomeric $\alpha, \beta$-diaminobutyric acids from amphomycin. J. Antibiotics 23: 149 154, 1970 